DOSSIÊ

\title{
Tempos de pandemias no capitalismo contemporâneo: \\ gig economy, direito do trabalho e covid-19
}

Pandemic season in current capitalism: gig economy, labor rights and covid-19

Leonardo Moura L. C. de siqueila* Sora pedreila** victória vilas Boas***

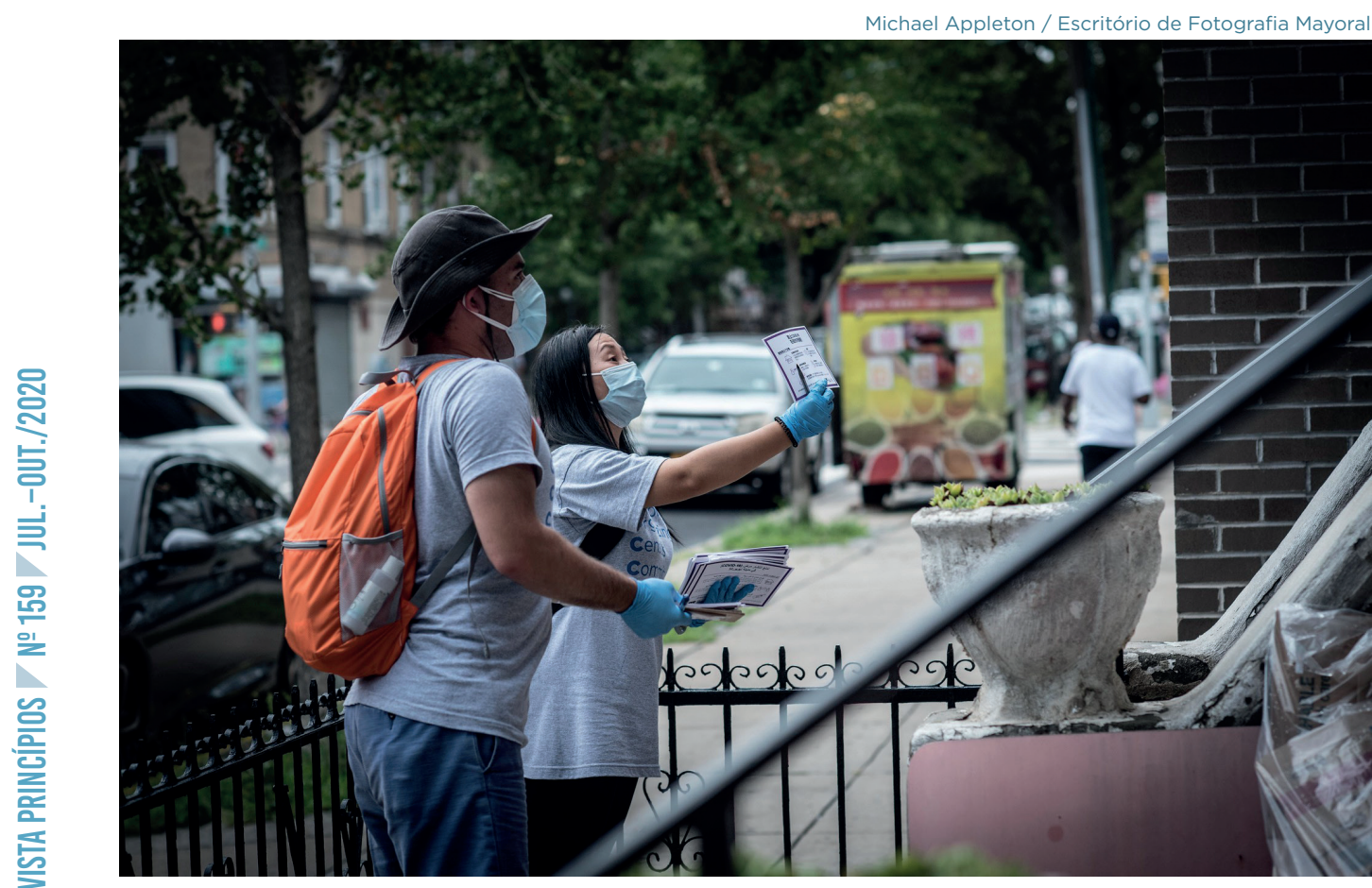

Voluntários testando trabalhadores comunitários em Sunset Park, Brooklyn. Agosto, 2020 


\section{RESUMO}

O objetivo do presente artigo é discutir as consequências da plataformização como nova forma de organização e gestão do trabalho. De forma mais específica, nele é analisada a atividade econômica de entregas em domicílio realizadas por trabalhadores contratados por empresas mediante cadastro em plataformas digitais, programadas para coordenar todas as etapas burocráticas e operacionais da prestação dos serviços.

Palavras-chave: Plataformização da economia; Trabalho; Emprego; Direito do trabalho.

\section{ABSTRACT}

The purpose of this article is to discuss the consequences of platforming as a new way of organising and managing working class labor. More specifically, it analyses the economic activities of home deliveries performed by workers hired by companies through digital platform registration, programmed to coordinate all the bureaucratic and operational stages of service provisions.

Keywords: Platform economy; Labour; Jobs; Labor rights.

\section{INTRODUÇ̃̃̃O}

Nos dias atuais, o mundo se vê em crise de saúde decorrente da velocidade de contágio do novo coronavírus. Entretanto, outra crise, essa de natureza socioeconômica, de forma também pandêmica, há mais de 40 anos vem se alastrando sorrateiramente no chamado mundo do trabalho. Para essa dimensão objetiva da vida social, o ano de 2020, com o advento da pandemia da covid-I9, poderá ser certamente analisado como aquele que tornou ainda mais evidente o processo de precarização social do trabalho, expondo com maior nitidez as fragilidades às quais a classe trabalhadora vem sendo há muito sujeitada.

No processo histórico de desenvolvimento do capitalismo, as últimas quatro décadas foram marcadas pela ampla adoção do receituário neoliberal no campo da política, pela globalização econômico-financeira e, no âmbito da produção em si, pela contínua reformulação da organização e da gestão do trabalho (ANTUNES, 2009; 20I8). Nesse sentido, os avanços tecnológicos realizados nesse período foram a base que permitiu ao capital reconfigurar sua estrutura produtiva, conferindo maior flexibilidade ao processo de acumulação, em função, dentre outras razões, de um mais acurado controle na exploração da força de trabalho.

Nos últimos dez anos, testemunha-se o fenômeno da plataformização das empresas, que, baseadas em infraestruturas digitais, tornam-se capazes de monitorar, gravar e analisar infinitas quantidades de dados sobre o comportamento das pessoas 
(trabalhadores e consumidores) gerados durante a realização de suas atividades econômicas. Embora, como destacado por Srnicek (20I7), empresas de distintos ramos de atividade tenham revisado ou construído seus modelos de negócio com base nesse novo ferramental, merecem destaque, pelo poder de exploração da força de trabalho, as empresas que cuidam dos serviços de delivery (iFood, Glovo, Deliveroo, Rappi, Uber Eats, Postmates, Lieferando) e de transporte urbano de passageiros (Uber, Cabify).

Com o crescimento exponencial do contágio pelo novo coronavírus, e as populações forçadas a adotar o isolamento social, o capitalismo vivencia uma desaceleração econômica inesperada, repentina, de intensidade e abrangência geográfica nunca antes observadas. Sua fragilizada sustentação é em parte viabilizada pela manutenção das atividades dessas empresas, cuja demanda, em função da quarentena, cresceu significativamente(SALOMÃO, 2020; PRESIDENTE..., 2020). Não por acaso, essas atividades foram classificadas dentre as essenciais (BRASIL, 2020a), posicionando os trabalhadores que as realizam em contínua exposição ao risco de contágio.

Nesse sentido, o objetivo do presente artigo é discutir as consequências, para a classe trabalhadora, da plataformização como nova forma de organização e gestão do trabalho. De forma mais específica, nele é analisada a atividade econômica de entregas em domicílio realizadas por trabalhadores contratados por empresas mediante cadastro em plataformas digitais, programadas para coordenar todas as etapas burocráticas e operacionais da prestação dos serviços.

Os argumentos aqui desenvolvidos têm por lastro uma revisão crítica de parte da bibliografia produzida por pesquisadores de diversos países e a análise de decisões jurídicas sobre a natureza da relação entre as empresas e os trabalhadores no Brasil e no exterior, bem como uma série de dados primários, coletados em pesquisa realizada em Salvador (BA), e secundários, oriundos de levantamento feito pela Aliança Bike na maior cidade brasileira, São Paulo. Os dados da investigação na capital baiana provêm de 3I entrevistas com trabalhadores de quatro empresas de delivery (I7 motoboys e I4 bikers), efetivadas entre 20/5/2019 e 19/2/2020, mediante a aplicação de questionário semiestruturado e captura de telas dos celulares cedidas por alguns dos entrevistados, não dando margem a dúvidas quanto às informações aqui trazidas. Assim sendo, essa investigação analisa a realidade brasileira, tendo como eixo de comparação os casos internacionais da Alemanha, Argentina, Espanha, Estados Unidos e França.

Além desta introdução e das considerações finais, o texto conta com mais quatro partes. Na primeira, é trazida uma visão panorâmica das transformações verificadas no mundo do trabalho nas últimas quatro décadas, que têm no trabalho mediado por aplicativos um dos seus pontos culminantes. Em seguida, são tecidos mais detalhes sobre essa nova forma de gestão do trabalho. Na terceira parcela, são trazidos alguns fatos que apontam as tendências das decisões judiciais sobre o trabalho plataformizado no Brasil e no mundo. Posteriormente, são analisadas as consequências iniciais da pandemia da covid-I9 sobre os trabalhadores dos serviços de entrega mediados por aplicativos. 


\section{A CRESCENTE OFENSIVA AO TRABALHO NOS ÚLTIMOS 40 ANOS}

Compreender os fenômenos do capitalismo no século XX é fundamental para investigar as metamorfoses contemporâneas do mundo do trabalho e como a pandemia do novo coronavírus tem impactado os trabalhadores em todo o mundo (ANTUNES, 2005, 2009). Nesse sentido, deve-se ter em vista que as políticas econômicas, a regulamentação, a organização do trabalho e as relações sociais são reflexos do modelo de acumulação capitalista vigente em cada período histórico (DUTRA, 20I4; PAULANI, 2009).

Nos 25 "anos dourados do capitalismo "que sucederam à Segunda Grande Guerra, verificou-se, nas principais estruturas socioeconômicas europeias, a consolidação do Estado de bem-estar social (welfare state), como uma resposta engendrada no seio do capitalismo para a assimetria de poder entre capital e trabalho, em um contexto histórico em que os ideais socialistas, com participação política ativa da classe trabalhadora, se apresentavam como alternativas objetivas factíveis (HOBSBAWM, 1995). Essas duas décadas e meia foram marcadas, assim, pela estruturação de sistemas sociais de proteção à classe trabalhadora, consolidando direitos que seriam, principalmente a partir dos anos I980, alvo de forte ofensiva do capital.

Esse movimento contra o Estado de bem-estar social foi desencadeado, ao longo dos anos I970, como resultante da interação de três distintos, simultâneos e sinérgicos processos, que corroboraram a transformação da ordem econômica, política e social no sistema capitalista, quais sejam: a ascensão do receituário neoliberal na agenda política das principais economias do sistema, a reestruturação produtiva dos grandes conglomerados empresariais e a globalização econômica e financeira do capital (DRUCK, I999; ANTUNES, 2009; FILGUEIRAS, 2000). A partir de então, processa-se a transição de um modelo que tinha na proteção social ao trabalho um dos seus pilares para um modelo de acumulação flexível (HARVEY, 2008), no qual a flexibilidade é uma característica-chave para compreender e assimilar tais processos.

Flexibilizado também, e de forma cada vez mais intensa, passaria a ser o mundo do trabalho, dimensão do sistema em cujo âmbito o objetivo maior por parte do capital no referido período histórico é retomar as condições pregressas de máxima exploração da força de trabalho. Perseguida com esse propósito, a flexibilidade das relações no campo do trabalho tem o papel fundamental de escamotear os vínculos empregatícios, possibilitando assim a negação aos direitos estabelecidos.

Em resposta à crise do modelo fordista de produção e servindo como uma das bases orientadoras da reestruturação produtiva, o toyotismo se expandiu do Japão para as outras economias centrais do sistema, reduzindo os custos produtivos, elevando a intensidade da exploração da força de trabalho e exigindo novos contratos, novas normas do trabalho e trabalhadores também flexíveis (CHESNAIS, I996; DRUCK, I996; HARVEY, 2008).Peculiar a esse modelo produtivo e por ele difundido, a terceirização constitui uma modalidade de trabalho assalariado predominante en- 
tre empresas de dimensões desproporcionais, isto é, empresas de pequeno e médio portes oferecem subcontratações a empresas grandes (DRUCK, I999; FILGUEIRAS, 20I6). O novo paradigma, sob a lógica da redução de custos e desperdícios da produção sob demanda, converteu o processo produtivo para o sistema just-in-time, cujo princípio, na medida do possível, também passa a ser aplicado para a mercadoria força de trabalho. Além de minimizar os estoques de insumos e produtos, as empresas optam por terceirizar ao máximo as parcelas dos seus processos produtivos e por encolher o quadro de funcionários, organizando o trabalho em equipes e estabelecendo metas de produtividade como forma de acelerar e intensificar o trabalho, evitando perdas com tempos mortos. O novo trabalhador ambicionado pelas empresas deve ser eficiente na realização de múltiplas funções e criativo para inovar, carismático para trabalhar em equipe, disponível e versátil para atender às demandas a qualquer momento: um trabalhador flexível e polivalente. Essa mesma maleabilidade também é aplicada crescentemente à jornada, cada vez mais indefinida, e à remuneração do trabalho, cuja parcela variável, calculada de acordo com a produção, vai se tornando cada vez mais significativa ante a fixa, precarizando as condições de reprodução do trabalho e ampliando as possibilidades de exploração(ANTUNES, 2005;2009).

No desencadear dessas transformações do seu sistema de produção e vida, o capital, não encontrando respaldo legal para as novas exigências da flexibilidade da produção, tem no campo da legislação trabalhista um ambiente de incessantes disputas políticas, com as instituições de regulação do trabalho podendo legalizar ou atenuar o processo de flexibilização imbuído da lógica neoliberal (DUTRA, 20I4; FILGUEIRAS, 20I9). Comprovam esse fato as sucessivas reformas trabalhistas verificada sem vários países (FILGUEIRAS; SOUZA; OLIVEIRA, 20I9; LINS; SILVA, 20I9), em geral impactando negativamente a classe trabalhadora, ampliando, de um lado, o exército de reserva de força de trabalho, e, de outro, uma massa de trabalhadores precarizados e desassistidos de direitos fundamentais(ANTUNES, 2005; 2019; FILGUEIRAS, 20I6) ${ }^{1}$.

1 Via de regra, as reformas facilitaram a legalização dos trabalhos atípicos, enquanto foram estabelecidas "novas" formas de contratação, associadas à retórica da flexibilização e da modernização das leis trabalhistas, em direção ao combate ao desemprego e a uma suposta adaptação às mudanças tecnológicas, à competição internacional e à globalização (FILGUEIRAS, 2019).No Brasil, a reforma trabalhista de 2017 caminhou na mesma direção que nos demais países, dada a similitude da retórica que a defendeu, prometendo a melhoria dos negócios dos empregadores e a melhoria de vida dos trabalhadores (FILGUEIRAS; PEDREIRA, 2019). Entretanto, o que de fato se verifica é: 1) uma tendência à redução dos direitos e da proteção do trabalhador; 2) um discurso orientado para a ideia do afastamento entre empregadores e empregados, muitas das vezes negando a condição de assalariamento e a real natureza das relações de trabalho (FILGUEIRAS; PEDREIRA, 2019).Dentre os contratos nos quais as empresas negam seu papel de empregadoras, há a ocorrência: a) do uso de um ente interposto, assumindo a relação da terceirização ou não, por exemplo na contratação de pessoas jurídicas (PJs), de microempreendedores individuais (MEIs) ou de trabalhadores "integrados"; b) da relação direta entre empresa e trabalhador, negando-se o vínculo empregatício, como no exemplo dos trabalhadores autônomos (FILGUEIRAS, 2016), ou negando-se o assalariamento, no caso de empresas como a Uber. Em ambas as situações, a flexibilidade é um aspecto basilar que acarreta a redução ou supressão de direitos para os trabalhadores e a liberdade para os empregadores estipularem as condições de trabalho, as jornadas e a remuneração (FILGUEIRAS, 2016). 


\section{O fenômeno da negação da relação de} assalariamento tem sido amplamente assimilado como uma "nova" forma de trabalho e camuflado pelos rótulos de trabalho autônomo ou de neoempreendedorismo, com o objetivo de subtrair direitos e flexibilizar os institutos do trabalho em todos os aspectos

Nos mais recentes anos, embora a negação da condição de empregador não seja uma novidade, dado o espraiamento da prática da terceirização como ferramenta da gestão do trabalho, o fenômeno da negação da relação de assalariamento tem sido amplamente assimilado como uma "nova" forma de trabalho e camuflado pelos rótulos de trabalho autônomo ou de neoempreendedorismo, com o objetivo de subtrair direitos e flexibilizar os institutos do trabalho em todos os aspectos (ANTUNES; FILGUEIRAS, 2020; FILGUEIRAS; PEDREIRA, 20I9).

Nesse contexto, potencializada pelo avanço das tecnologias de informação e comunicação (TICs), a gig economy (economia de bicos) tem ganhado protagonismo, fortalecendo a lógica da prestação de serviços por trabalhadores supostamente autônomos, contratados por meio de plataformas digitais (ANTUNES; FILGUEIRAS, 2020). As empresas por trás dessas ferramentas as desenvolvem com vistas ao exercício de atividades econômicas em que possam se aproveitar da enorme massa de trabalhadores disponibilizada pelo sistema para a realização de pequenas tarefas contratadas absolutamente just in time e remuneradas exclusivamente pela execução destas. A ferramenta digital possibilita o cadastro dos inúmeros trabalhadores que estão dispostos a prestar serviços designados e geridos remotamente também pela empresa por meio da plataforma.

Gig economy, crowdwork, platform economy, sharing economy, on-demand economy, work on demand, uberização e outras expressões têm sido amplamente utilizadas na academia, no meio empresarial e nas instituições de regulação do trabalho para designar trabalhos remunerados pela efetivação de cada atividade demandada (GINÈS I FABRELLAS, 20I8). Embora não tenham uma definição precisa, estão correlacionadas e convergem para um sentido semelhante: negar o vínculo empregatício e todos os direitos sociais que dele decorrem (ANTUNES; FILGUEIRAS, 2020).

As últimas quatro décadas, em suma, foram marcadas por feroz ofensiva do capital contra o trabalho em todo o mundo, considerando o enfraquecimento dos direitos laborais e a constante flexibilização das formas de exploração, em uma tendência à rotulagem do "velho trabalhador" como suposto "novo empreendedor". 


\section{PLATAFORMIZACÃO: VELHOS TRABALHADORES, NOVOS "EMPREENDEDORES"?}

As supostas novas formas de contratação, baseadas na plataformização das empresas, introduzem uma nova lógica de gestão da força de trabalho. As organizações apresentam-se como empresas de tecnologia, intermediárias entre consumidores e entregadores, constituindo um mercado de dois lados com externalidades cruzadas por redes (VALENDUC, 2019). Assim, essas empresas advogam criar uma ponte que beneficia ambos os lados desse mercado dual, de forma a não estabelecer vínculos empregatícios com as partes envolvidas.

A retórica utilizada é de suma importância para desenvolver essas novas formas de organização do trabalho, cumprindo papel essencial no sustento da gig economy. Isso porque a desconstrução do conceito de emprego, a reformulação da categoria de trabalhador e a substituição do trabalho assalariado pelo precariado, zona cinzenta ou trabalho autônomo são um processo político (VALENDUC, 20I9; ANTUNES; FILGUEIRAS, 2020). A persistente tentativa de transformar os trabalhadores em empreendedores de si mesmos está conectada ao discurso que relaciona direitos trabalhistas ao desemprego, e culmina na ideia de que "o sucesso só depende de você"(FILGUEIRAS, 20I9).

O fenômeno do trabalho por plataforma e por aplicativos de delivery é um exemplo recorrente desse tipo de contratação, em que os pseudonovos empreendedores não estão cobertos pelo direito do trabalho, ainda que estejam subordinados às ordens e direções das empresas prestadoras dos serviços, proprietárias da ferramenta digital. Nesse contexto, analisaremos quais instrumentos argumentativos têm sido comumente aplicados pelas principais empresas de delivery via apps, restringindo nossa análise inicial às empresas Uber Eats, Rappi e iFood. Para isso, buscamos suas declarações em seus sites, blogs, cartas abertas à imprensa e termos de uso e condições para o acesso à plataforma.

Verificamos claramente que, embora as empresas declarem em seus termos que seu serviço é prover uma plataforma digital para conectar trabalhadores e clientes, em seus sites e propagandas o negócio que elas desenvolvem se volta para as atividades de delivery.

No site oficial da Rappi, um dos anúncios da página diz: "Receba suas compras em casa em menos de I hora" 2 . Em um tweet da conta oficial da Rappi Brasil, a empresa afirma: "Pois fiquem sabendo que a Rappi te [sic] ajuda, tá [sic] ok? Agora temos um botão chamado Rent Umbrella (SP), [pelo] que você pede seu guarda[-]chuva rapidinho [sic] ou, então, pode pedir [a] um [funcionário da] Rappi pra [sic] buscar o seu em casa” (RAPPI BRASIL, 2020). Ambas as situações colocam a Rappi como a responsável pelo delivery, ou seja, não é um entregador autônomo, mas sim a Rappi a responsável por garantir a efetivação das entregas e por ajudar o cliente que pede "um Rappi".

Exemplos parecidos ocorrem nas mídias sociais da Uber Eats. No site oficial da empresa, a divulgação do serviço ofertado sugere: "Seu prato favorito com entrega da

2 Anúncio identificado em <www.rappi.com.br>, em 17/6/2020. 


\section{Embora as empresas declarem em seus termos que seu serviço é prover uma plataforma digital} para conectar trabalhadores e clientes, em seus sites e propagandas o negócio que elas desenvolvem se volta para as atividades de

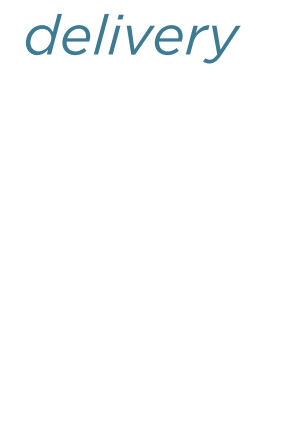

Peça da campanha "Delivery de tudo", feita pela agência IMAM Publicidade para a Rappi
Delivery de tudo em minutos

Entrega exclusiva MERCADOTECA

Use o código MERCADOTECA e ganhe $R \$ 20$ de desconto.

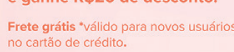

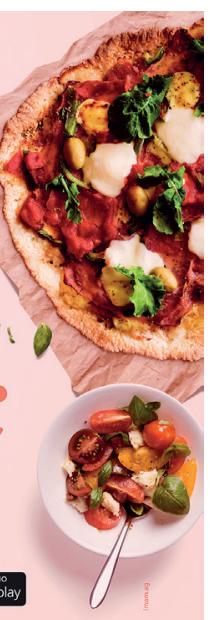

Uber" ${ }^{3}$. Na apresentação do seu $b \log ^{4}$, a empresa afirma: "Confira histórias, novidades sobre eventos e feriados e saiba como o Uber Eats pode contribuir com entregas nas suas festas". A Uber, assim como sua concorrente anteriormente citada, não se coloca como mera intermediadora, mas sim como a responsável pelas entregas. É ela, não um parceiro autônomo, que oferta e presta esse serviço.

Mesmo diante de tais evidências, em reportagem realizada pela imprensa internacional (FAGUNDEZ, 20I9), a Uber e o seu braço empresarial de deliveries(Uber Eats) comunicaram que "os entregadores parceiros são independentes, escolhem como e quando utilizarão o aplicativo como geração de renda”. Também informaram que "no Brasil, 80\% dos entregadores parceiros ativos no Uber Eats passam menos de 20 horas da semana on-line", atribuindo aos seus entregadores a característica de trabalho por tempo parcial.

A empresa iFood, em sua atual forma de gestão do trabalho das entregas, diferentemente das outras empresas, possui duas modalidades de entregadores: os classificados como "nuvem" e os "operadores de logística" (OLs). Estes últimos possuem uma carga horária fixa e pré-estabelecida pela empresa, sob pena de multa em caso de descumprimento. Em nota ao Tecnoblog (SILVA, 20I9), a empresa afirma que conecta

3 Identificado em <https://www.ubereats.com/br>, em 2/5/2020.

4 Verificado em <www.ubereats.com/blog/pt-BR/brain-food>, em 2/5/2020. 
restaurantes aos parceiros de entrega, gerando oportunidade de renda para cerca de I2O mil entregadores independentes, que podem ficar disponíveis para entregas quando quiserem e operar por outras plataformas.

Em mais uma nota, a outro veículo de imprensa(AYER, 20I9), a iFood informa que segue a legislação e reforça que os entregadores são "um dos principais parceiros", afirmando, ainda, que:

A empresa reitera que suas atividades geram oportunidade de renda para milhares de entregadores e esclarece, ainda, que seus parceiros de entrega são autônomos, ou seja, podem se cadastrar na plataforma para realizar entregas de acordo com sua conveniência, e podem operar também por meio de outras plataformas.

Sobre processo jurídico(BRASIL, 202ob) que considerou improcedente o vínculo empregatício dos entregadores da iFood, em nota efusiva, Fabricio Bloisi, CEO da iFood, comemora a decisão favorável à empresa que dirige:

Celebramos essa decisão histórica no país e no mundo, que preserva o direito de profissionais optarem por atuar de forma flexível e destaca que a economia está mudando com as novas tecnologias [...]. Temos de pensar juntos em como criar leis modernas que, ao mesmo tempo, gerem a esses profissionais renda, oportunidade e bem-estar, trazendo crescimento e desenvolvimento econômico ao nosso país(FUTEMA, 2020).

A respeito de processo de similar natureza, a empresa Rappi teceu à BBC(MACHADO, 2020) comentário inverossímil, transcrito abaixo:

Estes, profissionais autônomos, atuam por conta própria, portanto, podem se conectar e desconectar do aplicativo quando desejarem. A flexibilidade permite que esses profissionais usem a plataforma da maneira que quiserem e de acordo com suas necessidades. Não há relação de subordinação, exclusividade ou cumprimento de cargas horárias.

Não por acaso, via de regra, os termos de uso elaborados unilateralmente pelas empresas e assinados digitalmente pelos trabalhadores buscam negar veementemente a constituição de vínculo empregatício, reafirmando a condição deles como autônomos e um posicionamento da empresa como simples prestadora de serviço de conexão entre demandantes e ofertantes no mercado de deliveries. Esse posicionamento pode ser verificado nas transcrições a seguir.

A relação mantida entre a OPERADORA e o ENTREGADOR não configura relações empregatícias de qualquer espécie, [(...) regendo-se] pelas normas de direito civil, não sujeitando as partes aos deveres decorrentes da legislação trabalhista, nem atribuindo às mesmas os direitos correspondentes, não constituindo a plataforma RAPPI ferramenta não essencial [N. do A.: quis-se dizer ferramenta essencial] para o desenvolvimento de sua atividade econômica e [concluindo- 
-se] que não há qualquer relação hierárquica, de dependência, [de] subordinação ou trabalhista entre o ENTREGADOR e a OPERADORA, podendo o ENTREGADOR livremente em qualquer momento realizar serviços de frente e entregas para quem desejar (RAPPI, 20I9).

Desde logo fica esclarecido ao USUÁRIO — o qual se declara ciente - que o serviço oferecido pelo ifood.com.br se relaciona apenas à intermediação (com opção de pagamento on-line) para comercialização de produtos alimentícios, não abarcando preparo, embalagem, disponibilização e entrega física (via motoboy ou outros meios) dos produtos, sendo esses quatro itens de responsabilidade integral do RESTAURANTE, a quem deverão ser direcionados quaisquer reclamos acerca de problemas decorrentes de vício, defeito ou inexecução da feitura, preparo e entrega de produtos alimentícios (IFOOD, 20I3, p. I).

Você reconhece que a Uber não é fornecedora de bens, não presta serviços de transporte ou logística nem funciona como transportadora, e que todos esses serviços de transporte ou logística são prestados por parceiros independentes, que não são empregados(as), nem representantes da Uber, nem de qualquer de suas afiliadas (UBER, 2020).

Em suma, apesar das particularidades de atuação de cada uma dessas empresas, todas alegam, usando a mesma retórica, a ausência de relação empregatícia. Baseadas em suposta autonomia dos trabalhadores para montar suas cargas horárias, sem exclusividade, controle ou subordinação a um chefe ou gerente, nem remuneração fixa. Destacam a flexibilidade dos entregadores como um aspecto positivo dessa lógica de trabalho, que corroboraria a tese de autonomia dos trabalhadores.

Para além do discurso das empresas, há a realidade objetiva dos trabalhadores que atuam na esfera tangível da gig economy, ou seja, realizam o efetivo labor responsável por sustentar tais companhias. Antunes e Filgueiras (2020) esquematizam as principais medidas explícitas utilizadas pelas empresas gig para controlar seus trabalhadores. Elas os submetem a uma avaliação prévia, demarcam qual tarefa será realizada, escolhem qual deles irá realizar a tarefa (sem lhes permitir captação de clientes), delimitam unilateralmente o modo de execução, o prazo e a remuneração, determinam como os trabalhadores devem contatar suas gerências, pressionam-nos a ser assíduos e usam o bloqueio e a dispensa como formas de controlar e disciplinar a força de trabalho.

Da mesma forma, Filgueiras e Pedreira (2019) explicam como as características das empresas gig de delivery implicam uma subordinação grosseira baseada no uso da ferramenta digital. O algoritmo programado humanamente pelas companhias toma a forma de um gestor da produção que a controla e direciona.

Nos termos da Organização Internacional do Trabalho(OIT), os elementos presentes nessa relação configuram uma situação em que o empregador trata o indivíduo como outro que não um empregado, no intuito de esconder seu status 
Nos termos da

\section{Organização}

\section{Internacional do}

Trabalho(OIT),

\section{os elementos}

\section{presentes}

nessa relação

\section{configuram uma}

situação em que o empregador trata

o indivíduo como

outro que não

um empregado,

no intuito de

esconder seu

status legal de

assalariado.

\section{A essência}

desse modelo

de trabalho é,

portanto, a de um

assalariamento

disfarçado legal de assalariado. A essência desse modelo de trabalho é, portanto, a de um assalariamento disfarçado. Nesse processo, o ferramental das plataformas é estratégico para a negação do vínculo empregatício, potencializando essa postura empresarial nas três distintas fases constituintes de uma relação típica de trabalho: $\mathrm{I}^{\mathrm{a}}$ ) na contratação, em lugar do tradicional contrato de trabalho, há um termo de uso da plataforma que posiciona o trabalhador como cliente da empresa; $2^{\mathrm{a}}$ ) na exploração, a transmissão e o processamento contínuos de dados possibilitam a delegação de tarefas e o monitoramento em tempo real da execução destas, com avaliação do trabalhador por parte dos clientes da empresa e aperfeiçoamento também contínuo da gestão mediada pelos algoritmos, o que possibilita ainda um nível de exploração individualizado, por trabalhador; $3^{\text {a }}$ ) por fim, na demissão, realizada por simples desligamento, sem a obrigação de justificativas legais.

É justamente pelo registro constante dos dados e ações de seus trabalhadores que regular o trabalho se torna, tecnicamente, fácil como nunca antes (ANTUNES; FILGUEIRAS, 2020). As rotas percorridas, o tempo computado em cada etapa do processo, as gorjetas recebidas com valor máximo estipulado, o registro das horas on-line no aplicativo à disposição da empresa, as tarefas recebidas e recusadas, os incentivos e bonificações ganhos são apurados automaticamente pelo algoritmo dos apps, possibilitando o total conhecimento das jornadas e condições de trabalho enfrentadas pelos trabalhadores.

Examinaremos, assim, as relações dos trabalhadores com as empresas a fim de identificar os aspectos que evidenciam tal fato enquanto um instrumento de burla ao direito do trabalho. Vamos nos basear na literatura produzida por pesquisadores que já investigaram as relações de trabalho na gig economy, além da coleta de dados primários realizada pelos autores. 
No âmbito do setor de entrega de mercadorias por aplicativos, a Aliança Bike (2019) realizou um estudo entre 20 e 30 de junho de 20I9, com 270 ciclistas entregadores que estavam havia pelo menos um mês na atividade. Os resultados demonstram, assim como a OIT (ILO, 20I8) e Moraes, Oliveira e Accorsi (20I9), uma alta rotatividade desses trabalhadores, com quase dois terços deles (65\%) trabalhando nesse meio por até 6 meses. No quesito escolaridade, $53 \%$ dos respondentes tinham até o ensino médio completo, e para $26 \%$ dos bikers entregadores essa atividade foi o primeiro emprego. Para 59\% dos entrevistados, essa ocupação foi uma saída contra o desemprego; para $86 \%$, significava a única fonte de renda, de forma que $57 \%$ trabalhavam todos os dias e $75 \%$ submetiam-se a uma jornada diária de mais de 8 horas.

Um entregador ciclista por aplicativo típico é homem, brasileiro, negro, com idades entre 18 e 22 anos, ensino médio completo, que estava desempregado e, agora, trabalha todos os dias da semana, 9 a Io horas por dia, auferindo um ganho médio mensal de R $\$ 992$, ou seja, menos que o salário mínimo vigente no país. Em média, os bikers entregadores de São Paulo, trabalham 9,4 horas por dia e ganham R\$936 por mês. Numa jornada de 44 horas semanais, eles receberiam $R \$ 762,66$, menos que o equivalente ao salário mínimo (ALIANÇA BIKE, 20I9).

Em média, eles se deslocam Io,3km até a região de trabalho, sendo que, quando interrogados sobre os problemas da atividade, I8\% apontaram a distância entre o local de residência e o trabalho. O problema mais relatado foi o tempo perdido entre as chamadas (3I\%), o que coincide com o argumento de Stanford (20I8) sobre as tarifas decrescentes em relação ao tempo de espera, e explicita a necessidade de cumprir tarefas em uma jornada sem limites. O medo de ser assaltado, referido por $20 \%$ dos entrevistados, revela não só um problema endêmico da sociedade brasileira como também a transferência do risco aos trabalhadores, que não contam com seguros ou proteções da empresa.

Segundo a Companhia de Engenharia de Tráfego de São Paulo (CET, 20I8), o número de acidentes fatais envolvendo motocicletas aumentou $19,2 \%$ no biênio 20I7-20I8, sendo, nesse último ano, a primeira vez que as mortes de motociclistas em acidentes de trânsito ultrapassaram as de pedestres, considerando a série histórica 2009-2018. Apesar de não haver na apuração desse indicador uma separação entre os motociclistas entregadores de aplicativo e os demais, há fortes indícios de que o aumento do número de trabalhadores de delivery pode ter colaborado com o incremento dos acidentes. Essa correlação indica a lacuna da segurança no trabalho desses motofretistas.

Na pesquisa por nós realizada entre 20/5/2019 e 19/2/2020 em Salvador (BA), foram entrevistados 3I entregadores das empresas Uber Eats, iFood e Rappi, sendo I7 motoboys e I4 bikers entregadores. Em média, os respondentes trabalhavam havia 4,6 meses para as suas respectivas companhias e o maior tempo de permanência registrado foi de I4 meses, confirmando a tendência à alta rotatividade desse trabalho identificada pelas pesquisas da Aliança Bike (2019), bem como pelas investigações da OIT 
(ILO, 20I8) e a realizada por Moraes, Oliveira e Accorsi (2019) sobre outras atividades laborais plataformizadas.

A jornada média semanal era de 6,2 dias para ambas as categorias, sendo que o valor mínimo dos pedidos entregues foi de $\mathrm{R} \$ 4,90$ para transportes por moto e de $\mathrm{R} \$$ 3,80 para os realizados com bicicleta. Não houve um consenso entre os entregadores acerca do menor valor pago pelas empresas, assim como não havia um valor exato para a remuneração pela quilometragem. Segundo os entrevistados, a remuneração por quilômetro estava em uma faixa de $\mathrm{R} \$ 0,60$ a $\mathrm{R} \$ 0,90$, o que denota uma possibilidade de variação de até 50\% nesse possível critério de remuneração e indica incerteza quanto ao valor pago por tarefa realizada.

Os bikers entregadores, em média, trabalhavam 6 dias na semana, Io,4 horas por dia, com uma jornada semanal de 62,3 horas; auferiam R \$I.Ioo ao mês. Proporcionalmente, em uma jornada de 44 horas, eles receberiam $\mathrm{R} \$ 780,64$ (menos do que o salário mínimo brasileiro), o que converge para os resultados apurados pela Aliança Bike (2019).Já os motoboys, em média, trabalhavam 6 dias por semana, 8,6horasdiárias, com uma jornada semanal de 5I,5 horas, com rendimento médio de R 2.200 por mês, sendo o ganho líquido de R\$I.5I2 mensalmente. Em uma jornada semanal de 44 horas, eles receberiam R\$I.889,04 por mês brutos, e R\$I.304,7I por mês líquidos, abatendo-se os custos com combustível e manutenção da moto.

A apuração desses fatos objetivos ajuda a desarticular o falacioso argumento da liberdade de autogestão, com definição da própria jornada de trabalho e renda por parte do trabalhador. Desde o século XIX, Marx alertava para esse tipo de engambelação por parte do discurso do capital quando este defendia o salário por peça ${ }^{5}$. À primeira vista, observando o fato muito superficialmente, tem-se a impressão de que cada trabalhador teria o poder de definir a magnitude da sua remuneração de acordo com a sua capacidade produtiva e o seu livre-arbítrio. Nas palavras do autor de O Capital, tal discurso é "uma verdadeira cloaca de todas as atividades apologéticas há muito apodrecidas" (MARX, 20I7, p. 62I). Premido pelas demandas básicas de reprodução da sua vida, cada trabalhador tem clareza ou, no mínimo, intuição do quanto precisa gerar para si de renda. Entretanto, ao iniciar sua jornada diária no serviço de delivery plataformizado, não tem como estimar com certeza quantas viagens ou quantos quilômetros necessitará percorrer, e a que preço, para suprir suas carências materiais.

Mas, se por um lado o trabalhador vivencia diariamente o aguilhão dessa incerteza, por outro, as empresas, com todo o manancial de dados de que dispõem e a capacidade de processamento dos seus big datas, conseguem, com alta precisão, aferir indicadores operacionais da atividade econômica por elas realizada 24 horas por dia, sete dias por semana, de forma a poder tomar as decisões empresariais que lhes conduzam a excelentes ganhos mediante a manipulação da multidão de trabalhadores que, inquestionavelmente, lhes estará à disposição em um mercado de trabalho estruturado para manter elevadas taxas de desemprego e informalidade.

5 Ver capítulo XIX de Marx (2017). 
Os critérios quantitativos de remuneração e duração da jornada de trabalho demonstram como esse modelo de labor não configura uma ocupação esporádica, mas sim a principal fonte de sustento da maior parte dos trabalhadores gig. Eles se somam às características subjetivas anteriormente delineadas, que capturam a evidente subordinação imposta pelas empresas; as particularidades dessa relação qualificam um modelo de gestão do trabalho que rejeita o seu caráter empregatício, escamoteia a relação de assalariamento e nega os direitos trabalhistas.

Nesse processo, o uso das tecnologias de informação e comunicação (TICs) apenas potencializa o controle e a subjugação da força de trabalho, sem modificar em quase nada a essência da relação trabalhista e da atividade econômica de prestação de serviços de delivery. Em contrapartida, a perda da proteção social desses trabalhadores é uma evidente consequência desse padrão gerencial (ANTUNES; FILGUEIRAS, 2020; FILGUEIRAS; PEDREIRA, 20I9; ILO, 20I6).

Diante de tais evidências e da abundância de dados disponíveis, o argumento de que as empresas gig não são compatíveis com as regulações trabalhistas não deve seguir como justificativa para a exploração sem limites da força de trabalho nem para a negação de direitos laborais básicos. Esquivar-se de toda responsabilidade para com seus trabalhadores, apresentando-se como simples plataformas, é o cerne dessa forma de organização do trabalho, condicionando a tática de fazer com que os órgãos judiciais responsáveis e os formuladores de políticas se concentrem na tecnologia que lhes serve apenas de ferramenta, em vez de observaremos serviços que as empresas efetivamente prestam (MISHEL, 20I8; MPT, 20I8).

\section{TENDÊNCIAS APRESENTADAS PELOS PODERES JUDICIÁRIOS NO BRASIL E NO MUNDO}

O conjunto dos fatos aqui apresentados corrobora a leitura de que o direito do trabalho é um campo de disputas e que, "como técnica de civilização da técnica", segundo o MPT (2018, p. 55),

Deve adaptar-se ao estado da arte desta última. Isto é, caso a faceta da organização da força de trabalho se modifique, deve o direito do trabalho se amoldar à nova forma em que se apresenta. Desse modo, afirma-se que a atuação do direito do trabalho perante essas novas formas de organização - que devem prevalecer em pouco tempo — é imprescindível, pois, como aconteceu na superação do fordismo pelo toyotismo, a tendência agora é que, cada vez mais, as empresas incorporem elementos desse novo tipo de organização do trabalho, justamente por seu potencial - e objetivo - de fuga à proteção trabalhista.

Dessa forma, diante do papel histórico do direito do trabalho como mitigador da assimetria de poder vigente nas relações do mercado laboral e, nos dias atuais, mais especificamente no caso do trabalho mediado por plataformas, torna-se funda- 


\section{O Assembly Bill 5 (AB5), legislação do estado da Califórnia que regula o trabalho na gig economy, entrou em vigor em janeiro de 2020 e já motivou disputas no âmbito judicial. Enquanto alguns advogam que a lei é danosa para o ambiente de negócios do estado-sede das maiores companhias da gig economy, como Uber e Cabify, outros acreditam que esse é um avanço para a regulação do trabalho}

mental o restabelecimento do acesso aos direitos que decorrem do reconhecimento do vínculo empregatício entre os entregadores e as empresas plataformizadas.

Mundo afora, alguns avanços têm sido registrados. No Reino Unido, em dezembro de 20I8, a Court of Appeals (segundo tribunal mais importante do país) reconheceu o vínculo empregatício dos motoristas da Uber, concedendo a eles direito a férias remuneradas e salário mínimo.

$\mathrm{Na}$ Espanha, em janeiro de 2020, o Tribunal Superior de Justiça de Madri ratificou a condenação da Deliveroo e seus entregadores foram identificados como falsos autônomos pela Inspeção do Trabalho. O TST de Madri estabeleceu critérios para a atuação da Glovo, nos quais também considerou os entregadores da empresa como falsos autônomos (ROCHA, 2020; GÓMEZ, 2020; OLÍAS, 2020). Na mesma linha, o Tribunal Superior de Justiça da Catalunha (TSJC) definiu, pela primeira vez, que os entregadores da Glovo são empregados, revertendo assim a decisão do Tribunal Social no 24 de Barcelona. A sentença reconhece que as ausências de jornada fixa e de férias não são elementos do contrato de trabalho, e sim consequências dele, e, portanto, não anulam a subordinação a que se submete o trabalhador (FIGULS, 2020).

$\mathrm{Na}$ Argentina, em 20I8, foi criada a Asociación de Personal de Plataformas (APP), o primeiro sindicato da categoria no país. Em março de 2019, o Tribunal Nacional do Trabalho de Primeira Instância no 37 condenou a Rappi por ter bloqueado três entregadores após defenderem a APP em luta pelo direito à sindicalização e ao reconhecimento do vínculo empregatício. Ela ordenou o desbloqueio dos entregadores para que pudessem continuar a prestar os serviços da mesma forma que faziam antes do bloqueio. A decisão, na época, não possuía antecedentes. No entanto, a sentença proferida declarava que havia "plausibilidade na lei", porque os trabalhadores prestavam serviços a pedido da empresa e a lei trabalhista argentina estabelece que a existência de prestação de serviços presume a existência do contrato de trabalho. A 
APP também solicitou o registro na carteira de trabalho, mas o pedido ainda não foi atendido(FALLO..., 20I9).

$\mathrm{Na}$ França, em março de 2020, uma sentença do Tribunal de Cassação deferiu o reconhecimento do vínculo empregatício a um motorista da Uber. A Câmara Social se baseou na subordinação imposta pela empresa ao trabalhador, no que concerne às tarifas, rotas percorridas, avaliações, bloqueios e monitoramento. E assim como o TSJC na Espanha, a decisão francesa argumenta que a livre escolha dos horários de trabalho não exclui por si só uma relação de subordinação. A decisão também cita que o motorista possuía apenas oito segundos para aceitar a corrida proposta, sem conhecimento do destino do passageiro, e que, após a recusa de três solicitações, ele recebia mensagem da empresa questionando os motivos das negativas. Assim, o Tribunal de Cassação concluiu que o status de trabalhador autônomo desse motorista da Uber era fictício; que a empresa endereçou diretrizes, supervisionou a execução e exerceu um poder de sanção sobre o trabalhador.

O Assembly Bill 5 (AB5), legislação do estado da Califórnia que regula o trabalho na gig economy, entrou em vigor em janeiro de 2020 e já motivou disputas no âmbito judicial. Enquanto alguns advogam que a lei é danosa para o ambiente de negócios do estado-sede das maiores companhias da gig economy, como Uber e Cabify, outros acreditam que esse é um avanço para a regulação do trabalho. O AB5 complementa outra lei que regulava o status de trabalhadores independente contractors (autônomos) e dá um tom incisivo para definir quais trabalhadores se encaixam na definição. Para isso, institui a realização de um teste conhecido como $\mathrm{ABC}$, que possui três critérios que devem ser preenchidos a fim de que o trabalhador possa ser reconhecido como autônomo. Caso qualquer um dos requisitos não seja satisfeito, automaticamente o trabalhador é definido como empregado formal, com direito a pagamento de horas extras e seguro-desemprego.

Os três requisitos são: I) que a pessoa esteja livre do controle e da direção da entidade contratante em conexão com a execução da tarefa, tanto no contrato quanto para sua execução de fato; 2) que a pessoa realize um trabalho fora do curso normal dos negócios da entidade contratante;3) que a pessoa esteja habitualmente envolvida em um comércio, ocupação ou negócio estabelecido de forma independente, da mesma natureza que a envolvida no trabalho realizado.

Logo após a divulgação da nova lei, em setembro de 20I9, a Uber e a Cabify pediram uma liminar para revogar o $\mathrm{AB}_{5}$, mas esta foi negada em Io de fevereiro de 2020.

No Brasil, o Poder Judiciário ainda tem tomado decisões que divergem entre si. Enquanto alguns autos de infração e acórdãos definem o reconhecimento dos direitos dos trabalhadores da gig economy, a primeira decisão sobre o assunto por parte do Tribunal Superior do Trabalho (TST), instância máxima da Justiça do Trabalho no país, vai em sentido contrário. No dia 5 de fevereiro de 2020 , o vínculo de um motorista da Uber foi negado, pautando-se a decisão na justificativa de que os motoristas podem recusar chamados, recebem de $75 \%$ a $80 \%$ do valor pago pelo usuário, podem escolher 
os dias em que trabalham, e que a política de avaliação dos motoristas pelos clientes nem sequer tangencia a subordinação, requerendo apenas um feedback quanto à qualidade dos serviços do condutor. Assim, a decisão alegou autonomia do trabalhador no desempenho das atividades, descaracterizando a subordinação.

No atual contexto de pandemia, com grande aumento da demanda pelos serviços de delivery, a necessidade de reconhecimento do vínculo empregatício e, consequentemente, dos direitos dele decorrentes, como será visto a seguir, se torna muito mais premente.

\section{A COVID-19 E SUAS CONSEQUUENCIAS IMEDIATAS SOBRE O TRABALHO PLATAFORMIZADO DE DELIVERY}

Em 2020, a pandemia da covid-I9 tem feito do isolamento social um imperativo a nações dos cinco continentes. Governos das principais nações adotaram a quarentena como política, na tentativa evitar o colapso dos seus sistemas de saúde e de proteger seus cidadãos. Essa medida teve como impacto uma abrupta redução da dinâmica da economia mundial que há anos já se encontra enfraquecida. No Brasil, a forte desaceleração econômica apresenta como um dos seus resultados mais significativos o aumento da taxa de desemprego, que já se fez sentir em março de 2020, mês da identificação dos primeiros sinais de avanço da Sars-Cov-2 no país, retornando a um patamar acima dos $\mathrm{I} 2 \%$.

Já naquele mesmo mês, notícias veiculadas pela imprensa deram conta de grande aumento na demanda pelos serviços de delivery, atentando para os indispensáveis cuidados de prevenção ao contágio a se ter com os trabalhadores do setor, para proteção deles próprios e de todos os demais cidadãos com os quais eles se relacionam (REIS, 2020; LARA; BRAGA; RIBEIRO, 2020; INGIZZA, 2020).

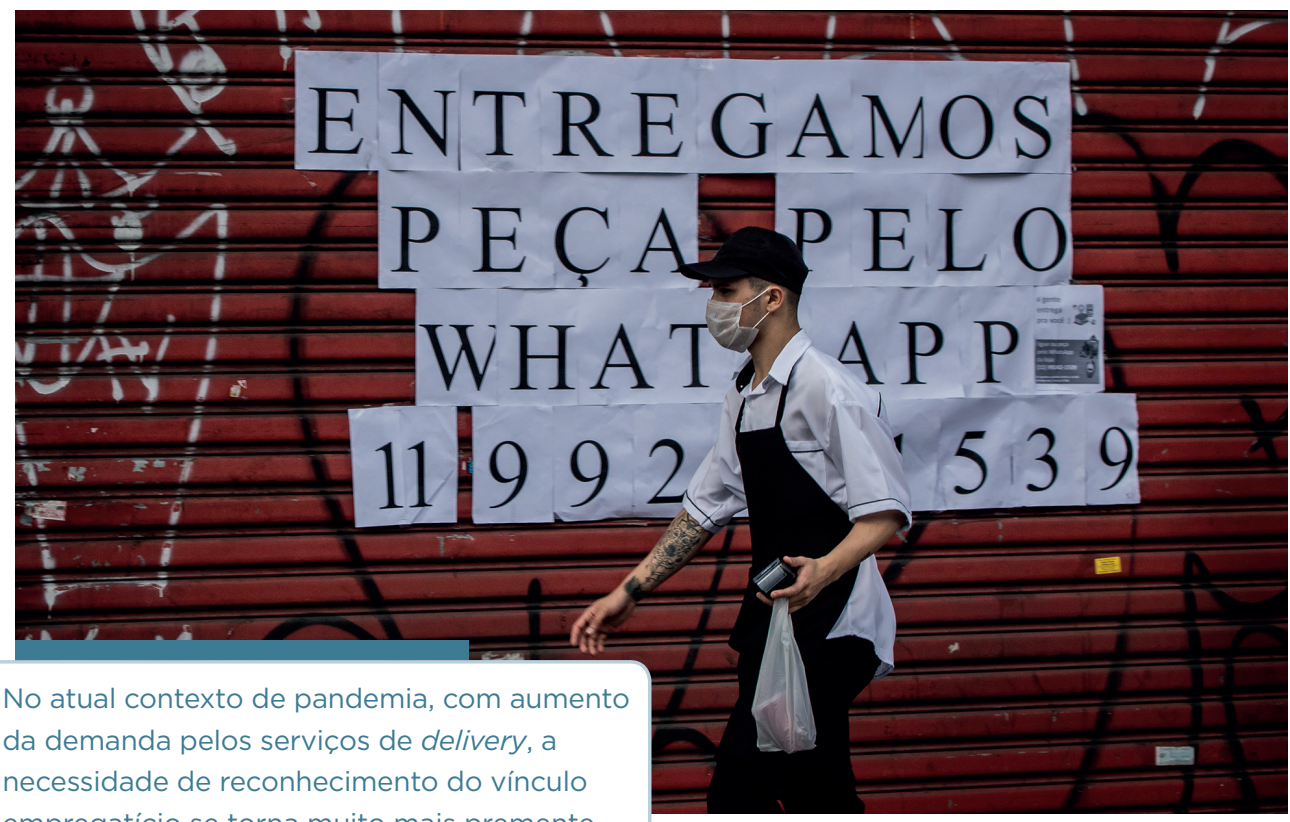

empregatício se torna muito mais premente 
Não demorou muito para que as empresas responsáveis por essa atividade econômica fossem instadas, inclusive pela Justiça, a cumprir o dever de orientar seus trabalhadores e lhes ofertar suporte para higienização pessoal e dos instrumentos de trabalho das entregas. Ainda em março, a Procuradoria Geral do Trabalho (PGT), em conjunto com a Coordenadoria Nacional de Combate às Fraudes nas Relações de Trabalho (Conafret), divulgou recomendações ao Ministério Público do Trabalho (MPT) e ao Governo do Estado de São Paulo, com base na "Nota técnica Conafret no oI/2020", a fim de orientar e subsidiar as medidas que deveriam ser adotadas diante da pandemia, para as empresas de transporte de mercadorias e passageiros, tendo em vista a vulnerabilidade e precariedade a que os trabalhadores estão sujeitos.

Em 4 de abril de 2020, uma ação cível pública (ACP) foi movida pelo Ministério Público do Trabalho contra a iFood, com vistas a garantir aos seus trabalhadores medidas preventivas à contaminação pelo Sars-Cov-2. A decisão em primeira instância deferiu as solicitações apresentadas, que obrigavam a empresa a, dentre outras ações: I) garantir ampla orientação aos trabalhadores e clientes, visando prevenir a transmissão da covid-I9; 2) fornecer insumos e estruturas de apoio à higienização dos trabalhadores e seus veículos; 3) garantir assistência financeira aos trabalhadores que fizessem parte do grupo de risco da doença ou que residissem com alguém desse grupo; 4) garantir assistência médica e financeira aos trabalhadores que viessem a contrair a doença.

Embora a decisão não se tenha pautado centralmente na natureza da relação empregatícia, ficou claro para o juiz responsável pelo caso que havia mais do que uma mera relação de intermediação entre a empresa e entregadores:

A investigação da natureza da relação de trabalho excede, a priori, o alcance desta ação, em que se busca tutela relacionada à saúde dos trabalhadores que atuam pelo aplicativo da ré, como indica o autor [...]. Não há dúvida, no entanto, de que a ré, ao menos, centraliza e organiza, por plataforma digital, a conexão entre trabalhadores e terceiros (empresas fornecedoras de produtos alimentícios e consumidores) (BRASIL, 2020c).

A decisão invocou ainda a Constituição Federal e a convenção no 155 da Organização Internacional do Trabalho para demonstrar a responsabilidade do Estado e das empresas em assegurar o cumprimento dessas normas de saúde, higiene e segurança: É direito dos trabalhadores, de forma ampla, a redução dos riscos inerentes ao trabalho, por meio de normas de saúde, higiene e segurança [...]. Parte da responsabilidade pela efetivação desse direito incumbe às empresas (convenção ${ }^{\circ}$ I55 da OIT, arts. I6/2I; decreto no I254/94 da Presidência da República). A lei no 8.080/9o, invocada pelo autor, dispõe que a saúde é direito fundamental do ser humano, cujo pleno exercício deve ser promovido pelo Estado, sem exclusão da responsabilidade de todos, inclusive das empresas (art. $2^{\circ}$, caput e parágrafo $2^{\circ}$ ). Também a lei 13.979/20, ao dispor sobre medidas 
para enfrentamento da emergência de saúde pública, incorpora as diretrizes do Regulamento Sanitário Internacional (art. $2^{\circ}$, parágrafo único; $\operatorname{art.} 3^{\circ}, \$ 2^{\circ}$, III); este, em seu art. I8, "2", estabelece a possibilidade de implementação de tratamento, entre outros, de meios de transporte, mercadorias e encomendas, a fim de remover infecção ou contaminação. Ainda de forma ampla, a natureza das atividades da ré impõe responsabilidade objetiva sobre eventuais danos causados aos prestadores de serviços (CC 927) (BRASIL, 2020c).

Todavia, em segunda instância, foi concedida liminar para suspensão dos efeitos da decisão da ACP, argumentando-se ser exíguo o prazo para efetivação das ações e elevada a multa diária prevista em caso de descumprimento destas. Adicionalmente, assumiu-se que a iFood não se enquadraria na definição de empregador contida no art. $2^{\circ}$ da CLT e que os entregadores seriam usuários da plataforma on-line, livremente inscritos (processo $n^{\circ}$ Iooo954-52.2020.5.02.0000). Ressalta-se ainda que a relação, por hipótese, seria de atividade econômica compartilhada, e que a análise não poderia se prender aos modelos tradicionais, devendo considerar a evolução das relações comerciais e trabalhistas.

Apesar da resistência apresentada pelas empresas, o movimento de adoção de precauções se tornou imperativo nos mais diversos países em que elas atuam, com diferentes medidas sendo tomadas.

No Brasil, segundo o site da Uber, os motoristas ou entregadores parceiros por ela mobilizados que fossem diagnosticados com covid-I9 ou posto em isolamento por médico licenciado ou autoridade de saúde pública seriam assistidos financeiramente por até I4 dias (UBER BLOG, 2020). Os trabalhadores também poderiam pedir reembolso por uma compra de álcool em gel, máscaras ou luvas, seguindo critérios definidos pela Uber, ainda a serem informados (RIBEIRO, 2020). A Rappi, embora não evidenciasse em seu site as medidas adotadas, alegava estar realizando a distribuição de material de higiene para os entregadores (PICHONELLI, 2020). Já a iFood divulgou oficialmente, além da distribuição de álcool em gel e de materiais informativos acerca do novo coronavírus, a criação de um fundo de R 2 milhões para dar assistência aos entregadores (R I milhão para os trabalhadores que testarem positivo ou forem postos em quarentena por suspeita de contágio e R I milhão para os que façam parte do grupo de risco ou resida com alguém desta população. A irônica diferença é que o fundo de assistência da iFood destinado aos restaurantes era25 vezes maior do que o dos entregadores (IFOOD, 2020a; PICHONELLI, 2020).

Para receber a assistência, o entregador, ao solicitar o afastamento, ficaria com a conta automaticamente inativa por $\mathrm{I} 4$ dias, devendo enviar em um prazo de 30 dias as evidências que comprovassem a necessidade. Uma das questões levantadas pelos próprios trabalhadores era que, para receber o auxílio financeiro das empresas, eles precisariam apresentar um teste positivo para o Sars-Cov-2. No entanto, muitos deles não estavam tendo acesso aos testes, prioritariamente destinados a pessoas com sinto- 
A pandemia evidencia as condições sociais precárias nas quais se encontram os trabalhadores plataformizados. Ao provocar grande aumento na demanda pelos serviços de entrega, ela amplia as jornadas e a exposição dos trabalhadores ao risco de contaminação e adoecimento, em um contexto jurídico de veemente recusa ao reconhecimento do vínculo empregatício e, consequentemente, de negação dos direitos trabalhistas e da mínima seguridade social deles decorrentes

mas mais graves. Outros tantos trabalhadores, ainda que não infectados, necessitariam ficar em isolamento social, por pertencerem ao grupo de risco ou morarem com pessoas incluídas nele (IT..., 2020; USTEK-SPILDA et al., 2020a). Entretanto, mesmo com o anúncio do auxílio financeiro, vários temiam ser desligados da plataforma e perder a sua única fonte de renda. Por isso, frequentemente continuavam se arriscando nas ruas, até mesmo adoentados, como no caso registrado de trabalhador na Inglaterra que, sem alternativa, seguiu trabalhando até não mais suportar e vir a falecer (BOOTH, 2020).

Nos Estados Unidos, a empresa de delivery DoorDash disse disponibilizar gratuitamente luvas e desinfetantes para mãos aos trabalhadores, cobrando-lhes, porém, uma taxa de frete superior a US\$Io. O surpreendente é que a DoorDash pagava a eles apenas US\$2 por entrega realizada.

Naquele mesmo país, quando os contágios caminhavam para seu ápice, o CEO da Uber enviou uma carta ao presidente da República pedindo medidas de proteção e benefícios para os trabalhadores nesse contexto da pandemia. Ou seja: além da constante negação do vínculo empregatício com os trabalhadores, a empresa tentava imputar exclusivamente ao Estado a responsabilidade pela saúde e pela segurança deles.

Ainda no contexto internacional, a Fairwork, em parceria com a OIT, coletou informações sobre como cerca de I20 empresas da gig economy, atuantes em 23 países da Europa, América do Norte, América do Sul, Ásia e África, vinham agindo para atenuar os riscos a que se expõem os trabalhadores durante a pandemia e chegou a algumas conclusões congruentes com a postura do líder da Uber diante do governo dos EUA. No seu relatório de pesquisa, afirma que: 
Primeiro, existe uma lacuna entre a retórica e a realidade: as plataformas têm sido muito melhores em divulgar medidas do que em efetivá-las para os trabalhadores. Segundo, há um desvio no foco das partes interessadas: as respostas das plataformas atenderam a acionistas, investidores e clientes antes dos trabalhadores, mesmo sendo estes a base de todo o valor da plataforma. Há também uma pusilanimidade: enquanto os governos rasgaram ideologias e livros de regras, as plataformas geralmente têm sido apenas incrementais em seus posicionamentos, que frequentemente apresentam argumentos contratuais de fuga em vez da garantia de resposta. As plataformas imputam riscos e responsabilidades a outras pessoas: interpretam "lavar as mãos" menos em termos de prevenção ao vírus e mais em termos de responsabilidades para com os trabalhadores, jogando essas responsabilidades aos governos, pelo apoio financeiro, e aos trabalhadores individualmente, por sua própria proteção contra o coronavírus (FAIRWORK, 2020, p. 2, tradução nossa $)^{6}$.

No cenário brasileiro, embora as empresas alegassem ter aumentado as taxas pagas aos entregadores, protestos em São Paulo (SP) reivindicaram melhores remunerações e maior transparência das empresas, que seguiam com os bloqueios e desligamentos arbitrários. Alguns entregadores também reclamavam não ter recebido os kits de assistência, com álcool em gel, máscaras e material informativo. Em contrapartida, a Rappi registrou um pico de crescimento de $300 \%$ nos pedidos, além de ter triplicado o número de novos entregadores, enquanto a iFood cadastrou 23 mil novos entregadores de fevereiro a março de 2020.

Pesquisadores da Rede de Estudos e Monitoramento Interdisciplinar da Reforma Trabalhista (Remir)divulgaram durante o mês de abril relatório de investigação realizada mediante a aplicação eletrônica de questionário respondido por 252 entregadores de 26 cidades brasileiras ${ }^{7}$ (ABÍLIO et al., 2020). Os resultados revelaram que a grande maioria dos entregadores plataformizados percebeu significativa redução dos seus rendimentos depois do início da pandemia, mesmo após a maioria deles ter ampliado sua jornada diária de trabalho. Durante a pandemia, aumentou significativamente o número de trabalhadores com rendimento máximo de até R\$ 520 por semana, com clara maior representatividade daqueles que auferiram até $\mathrm{R} \$ 260$ por semana (gráfico I). Por outro lado, o número de trabalhadores com rendimentos semanais acima de $\mathrm{R}$ \$ 520 apresentou grande redução. Segundo o relatório publicado antes da pandemia, 49,9\% dos entrevistados tinham patamar de renda acima desse valor; a partir da pandemia, essa parcela decresceu para quase metade $(25,4 \%)$.

6 A publicação do referido relatório é preliminar. Previa-se que a divulgação da versão final do documento ocorreria até julho de 2020.

7 Segundo os pesquisadores, houve uma concentração de cerca de $80 \%$ dos respondentes em quatro cidades, quais sejam: São Paulo, Curitiba, Belo Horizonte e Recife. 
Gráfico 1- Distribuição do número de trabalhadores entrevistados por faixa de rendimento semanal antes e ao longo da pandemia, Brasil abril de 2020

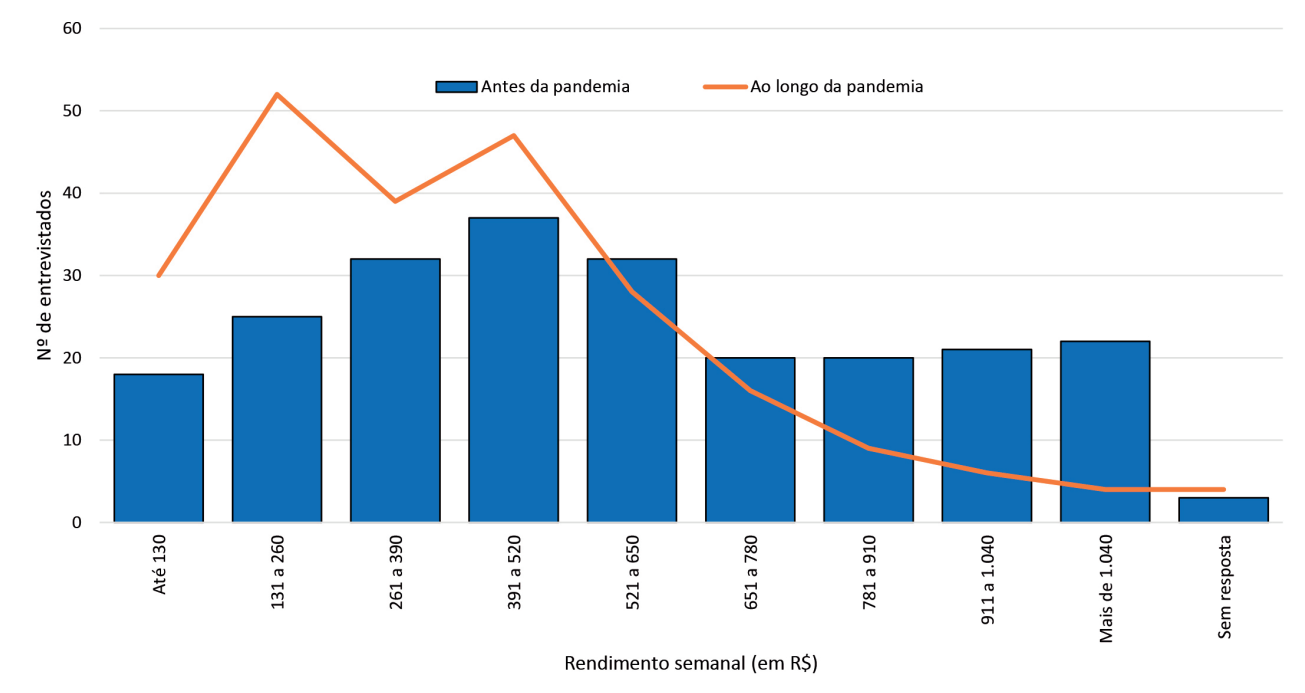

FONTE: Remir - GT Trabalho Digital

Quando observados pela perspectiva distributiva do tamanho da jornada diária de trabalho, em todos os intervalos de classe, pelo menos $55 \%$ dos trabalhadores guardavam a percepção de terem sofrido redução dos seus rendimentos. Este fato foi mais intensamente percebido por aqueles trabalhavam por jornadas mais longas, de 9 ou mais horas laborais por dia (gráfico 2).

Gráfico 2 - Percepção da variação no rendimento pelos trabalhadores das empresas de delivery a partir da pandemia da covid-19 por faixas de extensão da jornada, Brasil — abril de 2019

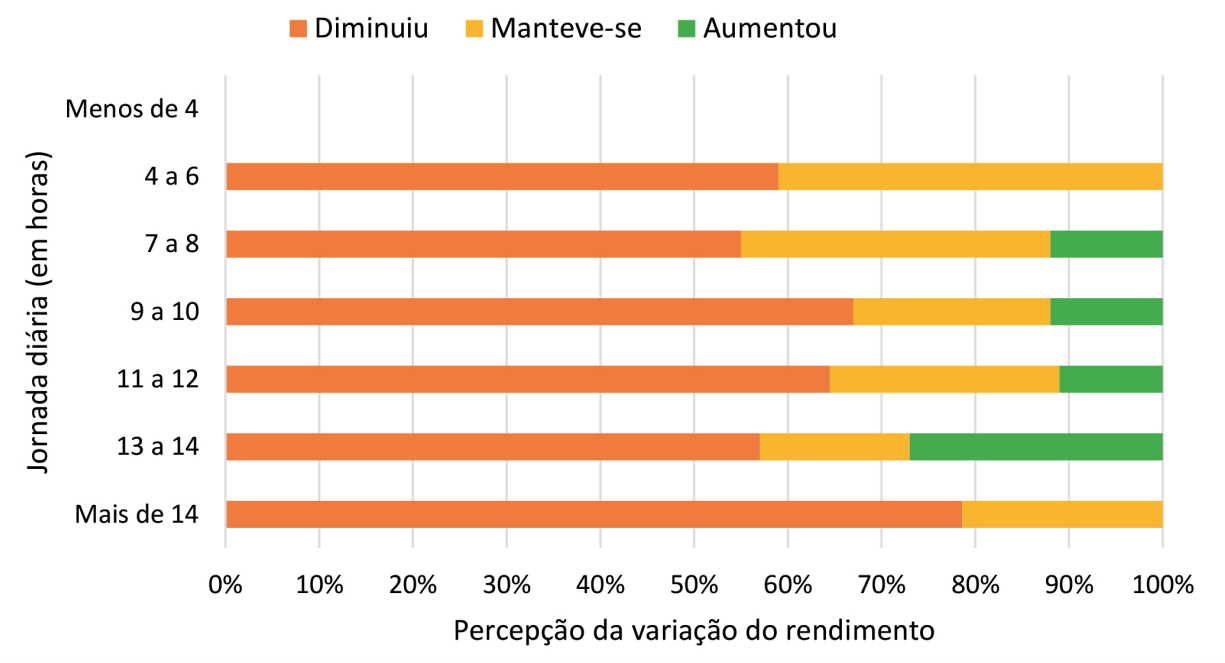


Outra séria estatística que denuncia a intensificação da precarização das condições de trabalho dos entregadores vem do Governo do Estado de São Paulo, que aponta um incremento de quase $50 \%$ no número de motociclistas mortos no segundo bimestre de 2020 em comparação com o mesmo período do ano anterior. Segundo o presidente do Sindicato dos Motoboys de São Paulo, Gilberto Almeida Santos (apud HENRIQUE, 2020), entrevistado pelo jornal Agora São Paulo,

"Cada aplicativo tem um modelo de remuneração, isso já prejudica a segurança [financeira] do entregador. E como tem muito trabalhador rodando com moto, o valor do frete despenca também. Com isso, os motoboys se arriscam fazendo várias corridas [sem cuidados] para compensar".

Grande parte dos trabalhadores gig, por não possuir nenhuma alternativa de renda, não pode se dar o luxo do isolamento neste período. Nesse sentido, é indispensável se levar em conta que a adoção da quarentena, enquanto política pública, se sacrificar o bem-estar daqueles com maior vulnerabilidade financeira, física e mental, é insustentável (USTEK-SPILDA et al., 2020b).

\section{BREVE NOTA CONCLUSIVA}

Períodos de mais agudas crises, como se verifica no atual contexto da pandemia da covid-I9, parecem ajudar a enxergar problemas que antes permaneciam latentes, denunciados apenas por aqueles habituados à lida com questões dessa natureza. No transformador momento presente, a pandemia evidencia as condições sociais precárias nas quais se encontram os trabalhadores plataformizados. Ao provocar grande aumento na demanda pelos serviços de entrega, ela amplia as jornadas e a exposição dos trabalhadores ao risco de contaminação e adoecimento, em um contexto jurídico de veemente recusa ao reconhecimento do vínculo empregatício e, consequentemente, de negação dos direitos trabalhistas e da mínima seguridade social deles decorrentes.

A redução dos valores pagos por entrega aos entregadores é mais um vilipêndio ao trabalho destes. Suas consequências, como denunciado pelas estatísticas de acidentes fatais com motociclistas da cidade de São Paulo, vão, como quase todos os aviltamentos aqui relatados, muito além da dimensão econômica da vida. $\mathrm{O}$ atual contexto afeta, por óbvio, não apenas os trabalhadores plataformizados, mas também toda a rede de relações sociais a eles vinculada.

Em suma, a covid-I9 potencializa as consequências perversas da negação de direitos posta em prática por meio do modelo plataformizado de gestão do trabalho. Os trabalhadores encontram-se, em meio à pandemia, em condição de extrema vulnerabilidade, desassistidos dos seus direitos fundamentais, ao passo que as empresas de delivery têm seus ganhos elevados, mantendo a transferência dos custos, riscos e responsabilidades aos entregadores, perversa e irresponsavelmente rotulados como 
"autônomos". As empresas, ao se valer das designações de aplicativos ou plataformas, empenham-se em convencer as instituições regulatórias da inexistência de assalariamento entre elas e seus trabalhadores digitais. $\mathrm{O}$ reconhecimento do vínculo empregatício é essencial para assegurar condições de trabalho dignas a todos os trabalhadores, pondo limites à exploração da classe trabalhadora (REMIR, 2020).

O panorama mundial está escancarando essas práticas ao mostrar como esses trabalhadores, enquanto elo mais frágil, não conseguem sobreviver dignamente sem a estrutura do direito do trabalho.

Ampliando a dimensão do problema que antes já se fazia presente no dia a dia de muitas pessoas, a pandemia desmascara as condições laborais invisibilizadas, trazendo consigo a oportunidade de resolvê-lo. A centralidade do trabalho e da classe trabalhadora na sociedade capitalista, condição que chegou ao ponto de ser questionada diante das intensas transformações verificadas a partir dos anos I980, está ratificada. É fundamental também ratificar os institutos que conferem civilidade a esta sociedade, revertendo o já longo processo de escusa do reconhecimento dos direitos trabalhistas, fundamentais para seu desenvolvimento enquanto modo de produção e vida.

* Doutorando em Economia pela Universidade Federal da Bahia (UFBA).

E-mail: leonardo.moura@gmail.com

** Graduanda em Economia pela UFBA.

E-mail: sarapedreira00@gmail.com

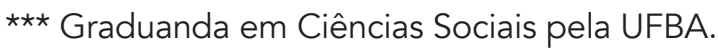

E-mail:victoria.vbs@hotmail.com

O presente artigo resulta de trabalho de pesquisa realizado no âmbito do "Projeto Caminhos do Trabalho", fruto de parceria institucional entre o Ministério Público do Trabalho e a UFBA, sob a coordenação do professor doutor Vitor Araújo Filgueiras.

Texto recebido em junho de 2020; aprovado em junho de 2020. 
ABÍLIO, Ludmila C. et al. Condições de trabalho em empresas de plataforma digital: os entregadores por aplicativo durante a covid-19. Relatório parcial de pesquisa. São Paulo: Remir, 2020. 11 p.

ALIANÇA BIKE. Pesquisa de perfil dos entregadores ciclistas de aplicativo. São Paulo, 17 jul. 2019. Disponível em: <http://aliancabike.org.br/pesquisa-de-perfil-dos-entregadores-ciclistas-de-aplicativo >. Acesso em: 11jun. 2020.

ANTUNES, Ricardo. O caracol e sua concha: ensaios sobre a nova morfologia do trabaIho. São Paulo: Boitempo, 2005.

Os sentidos do trabalho: ensaio sobre a afirmação e a negação do trabalho. São Paulo: Boitempo, 2009.

O privilégio da servidão. São Paulo: Boitempo, 2018.

; BRAGA, Ruy (Org.). Infoproletários: degradação real do trabalho virtual. São Paulo: Boitempo, 2009.

ANTUNES, Ricardo; FILGUEIRAS, Vitor Araújo. Plataformas digitais, uberização do trabaIho e regulação no capitalismo contemporâneo. Contracampo, Niterói, v. 39, n. 1, p. 27 43, abr./jul. 2020.

AYER, Flávia. Para Ministério Público do Trabalho, rotina dos motoboys é de exploração. Estado de Minas, Belo Horizonte, 15 mar. 2019. Disponível em: <www.em.com.br/app/ noticia/economia/2019/03/10/internas_economia,1036630/para-ministerio-publico-rotina-dos-motoboys-e-de-exploracao.shtml>. Acesso em 13 jun. 2020.

BOOTH, Robert. Uber driver dies from covid-19 after hiding it over fear of eviction. The Guardian, Londres, 17 abr. 2020. Disponível em: <www.theguardian.com/world/2020/ apr/17/uber-driver-dies-from-covid-19-after-hiding-it-over-fear-of-eviction?CMP=fb_ gu\&utm_medium=Social\&utm_source=Facebook\#Echobox=1587141008>. Acesso em: 13 jun. 2020.

BRASIL. Decreto n. 10.282, de 20 de março de 2020. Regulamenta a lei n. 13.979, de 6 de fevereiro de 2020, para definir os serviços públicos e as atividades essenciais. Brasília, 20 mar. 2020(a). Disponível em: <www.planalto.gov.br/ccivil_03/_Ato2019-2022/2020/Decreto/D10282.htm\#art3§1 viii>. Acesso em: 13 jun. 2020.

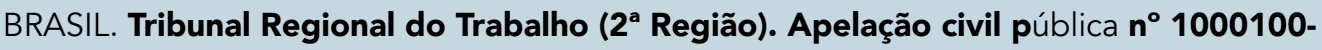
78.2019.5.02.0037. Apelante: Ministério Público do Trabalho. Apeladas: Rapiddo Agên- 
cia de Serviços de Entrega Rápida S.A.; Ifood Com. Agência de Restaurantes Online S.A. Relatora: Juíza Shirley Aparecida de Souza Lobo Escobar. 37ª Vara do Trabalho de São Paulo. São Paulo, 27 jan. 2020(b). p. 1-74. Disponível em: <https://pje.trt2.jus.br/consultaprocessual/detalhe-processo/10001007820195020037>. Acesso em: 22 abr. 2020.

\section{BRASIL. Tribunal Regional do Trabalho ( $2^{\mathrm{a}}$ Região). Ação civil pública com pedido de tutela de urgência n 1000396-28.2020.5.02.0082. Requerente: Ministério Público do Trabalho. Requerida: Ifood Com. Agência de Restaurantes Online S.A. Relator: Juiz do trabalho plantonista Elizio Luiz Perez. $82^{\mathrm{a}}$ Vara do Trabalho de São Paulo. São Paulo, 6 abr. 2020(c). p. 1-23. Disponível em: <https://pje.trt2.jus.br/consultaprocessual/detalhe- -processo/10003962820205020082>. Acesso em: 22 abr. 2020.}

CET. Relatório anual de acidentes de trânsito - 2018. São Paulo, 2019. Disponível em <http://www.cetsp.com.br/media/866316/relatorio-anual-2018-versao-28-05.pdf>. Acesso em: 23 jan. 2020.

CHESNAIS, François. A mundialização do capital. São Paulo: Xamã, 1996.

DRUCK, Maria da Graça. Globalização, reestruturação produtiva e movimento sindical. Caderno CRH, Salvador, n.24/25, p.21-40, jan./dez. 1996. Disponível em: <https://portalseer.ufba.br/index.php/crh/article/view/18647/12021 >. Acesso em: 12 jun. 2020.

Terceirização: (des)fordizando a fábrica. São Paulo: Boitempo, 1999.

DUTRA, Renata Q. Do outro lado da linha: Poder Judiciário, regulação e adoecimento dos trabalhadores em call centers. 2014. 294 f. Dissertação (Mestrado em Direito) —Faculdade de Direito, Universidade de Brasília, Brasília, 2014. Disponível em: <https://repositorio.unb. br/bitstream/10482/15608/1/2014_RenataQueirozDutra.pdf>. Acesso em: 17 jul. 2019.

FAGUNDEZ, Ingrid. Como ser "top": ubers viram youtubers e faturam ensinando segredo do sucesso a motoristas e entregadores. BBC News Brasil, São Paulo, 27 out. 2019. Disponível em: <www.bbc.com/portuguese/brasil-49884077>. Acesso em: 13. jun. 2020.

FAIRWORK. The gig economy and covid-19: fair work report on platform policies [versão preliminar]. Oxford, 2020. Disponível em: <https://fair.work/wp-content/uploads/sites/97/2020/06/COVID19-Report-Final.pdf>. Acesso em: 26 abr. 2020.

FALLO histórico: la justicia ordenó a Rappi reincorporar a trabajadores despedidos. Infonews, Buenos Aires, 20 mar. 2019. Disponível em: <www.infonews.com/despidos/ fallo-historico-la-justicia-ordeno-rappi-reincorporar-trabajadores-despedidos-n278756>. Acesso em: 3 maio 2020. 
FIGULS, Josep Catà. El Tribunal Superior de Cataluña declara que los repartidores de Glovo son assalariados. El País, Madri, 9 mar. 2020.Disponível em: <https://elpais.com/ economia/2020-03-09/el-tribunal-superior-de-cataluna-declara-que-los-repartidores-de-glovo-son-asalariados.html>. Acesso em: 21 abr. 2020.

FILGUEIRAS, Luiz. História do Plano Real. São Paulo: Boitempo, 2000.

FILGUEIRAS, Vitor Araújo. Regulação da terceirização e estratégias empresariais: o aprofundamento da lógica desse instrumento de gestão da força de trabalho. Cadernos do Ceas, Salvador, n. 239, p. 742-770, 2016.

As promessas da reforma trabalhista: combate ao desemprego e redução da informalidade. In: KREIN, José Dari; OLIVEIRA, Roberto Véras de; FILGUEIRAS, Vitor Araújo (Org.). Reforma trabalhista no Brasil: promessas e realidade. Campinas: Curt Nimuendajú, 2019. p. 13-52.

; SOUZA, Ilan Fonseca de; OLIVEIRA, Gabriela de Freitas. Os impactos jurídicos das reformas trabalhistas e a (re)mercadorização do trabalho nas experiências internacionais. Cadernos do Ceas, Salvador, n. 248, p. 514-543, set./dez. 2019.Disponível em:<https://cadernosdoceas.ucsal.br/index.php/cadernosdoceas/article/view/579>. Acesso em 15 jan. 2020.

FILGUEIRAS, Vitor Araújo; PEDREIRA, Sara Costa. Trabalho descartável: as mudanças nas formas de contratação introduzidas pelas reformas trabalhistas no mundo. Cadernos do Ceas, Salvador, n. 248, p. 578-607, set./dez. 2019.Disponível em:<https://cadernosdoceas.ucsal.br/index.php/cadernosdoceas/article/view/588>. Acesso em: 3 fev. 2020.

FUTEMA, Fabiana. Entenda por que a decisão pró-Ifood não encerra impasse sobre vínculo empregatício de entregadores de app. 6 Minutos, São Paulo, 28 jan. 2020. Disponível em: <https://6minutos.com.br/negocios/entenda-por-que-a-decisao-pro-ifood-nao-encerra-impasse-sobre-vinculo-empregaticio-de-entregador-de-app >. Acesso em: 13 jun. 2020.

GINÈS I FABRELLAS, Anna. Crowdsourcing: una modalidad juridicamente inviable de externalización productiva en el nuevo entorno digital. Anuario IET de Trabajoy Relaciones, Barcelona, v. 5, p. 133-145, 2018.

GÓMEZ, Manuel V. Trabajo busca un cambio legal para acabar con los falsos autónomos. El País, Madri, 2020. Disponível em: <https://elpais.com/economia/2020/02/21/actualidad/1582278047_708690.html>. Acesso em: 22 fev. 2020. 
GRANATO, Luísa. Como é a rotina de um motoboy em São Paulo na quarentena. Exame, São Paulo, 28 abr. 2020. Disponível em: <https://exame.abril.com.br/carreira/como-e-a-rotina-de-um-motoboy-em-sao-paulo-na-quarentena>. Acesso em: 3 maio 2020.

HARVEY, David. Condição pós-moderna. 17. ed. São Paulo: Loyola, 2008.

HENRIQUE, Alfredo. Morte de motociclistas cresce durante período de quarentena em SP. Agora São Paulo, São Paulo, 22 maio 2020. Disponível em: <https://agora.folha.uol. com.br/sao-paulo/2020/05/morte-de-motociclistas-cresce-durante-periodo-de-quarentena-em-sp.shtml?origin=uol>. Acesso em: 13. jun. 2020.

HOBSBAWM, Eric J. Era dos extremos: o breve século XX (1914-1991). São Paulo: Companhia das Letras, 1995.

IFOOD. Fundo solidário e proteção: o que você precisa saber. São Paulo, 21 mar. 2020(a). Disponível em: <https://entregador.ifood.com.br/fundos-perguntas-e-respostas>. Acesso em: 30 mar. 2020.

Termos e condições. São Paulo, 19 mar. 2013(b). Disponível em: $\leq$ www.ifood. com.br/termos>. Acesso em: 19 jun. 2019.

ILO. Digital labour platforms and the future of work: towards decent work in the online world. Genebra: International Labour Office, 2018. Disponível em: <www.ilo.org/wcmsp5/ groups/public/---dgreports/---dcomm/---publ/documents/publication/wcms_645337.pdf>. Acesso em: 12 jun. 2020.

Non-standard employment around the world: understanding challenges, shaping prospects. Genebra: International Labour Office, 2016. Disponível em: <www. ilo.org/wcmsp5/groups/public/---dgreports/---dcomm/---publ/documents/publication/ wcms_534326.pdf >. Acesso em: 12 jun. 2020.

INGIZZA, Carolina. Uber Eats começa a fazer entregas de farmácias, pet shops e conveniências. Exame, São Paulo, 1 abr. 2020. Disponível em: <https://exame.com/negocios/ uber-eats-comeca-a-fazer-entregas-de-farmacias-pet-shops-e-conveniencias $>$. Acesso em 13 jun. 2020.

IT would be selfish to continue to work, but I can't get a test \& I can't self-quarantine.

The Pay Up Campaign, Seattle, 15 mar. 2020. Disponível em: <https://payup.wtf/ blog/2020/3/15/gig-worker-coronavirus>. Acesso em: 21 abr. 2020. 
KHOSROWSHAHI, Dara [Presidente-executivo da Uber]. [Carta enviada para o presidente dos EUA]. Destinatário: Donald Trump. Washington, D.C., 23 mar. 2020. 1 carta. Disponível em: <https://blogadmin.uberinternal.com/wp-content/uploads/2020/03/UberLetter.pdf>. Acesso em 21 abr. 2020.

LARA, Bruna de; BRAGA, Nathália; RIBEIRO, Paulo Victor. Aplicativos lucram com coronavírus pondo entregadores em risco de contágio. The Intercept Brasil, São Paulo, 23 mar. 2020. Disponível em: <https://theintercept.com/2020/03/23/coronavirus-aplicativos-entrega-comida-ifood-uber-loggi>. Acesso em: 13 jun. 2020.

LINS, Vinicius Ferreira; SILVA, Adalberto Oliveira da. As reformas trabalhistas no mundo: a flexibilização no tempo de trabalho e na remuneração como vetor de precarização.

Cadernos do Ceas, Salvador, n. 248, p. 481-513,set./dez. 2019. Disponível em:<https:// cadernosdoceas.ucsal.br/index.php/cadernosdoceas/article/view/538>. Acesso em: 3 jan. 2020.

MACHADO, Leandro. Dormir na rua e pedalar 12 horas por dia: a rotina dos entregadores de aplicativos. BBC News Brasil, São Paulo, 22 maio 2019. Disponível em: <https://www. bbc.com/portuguese/brasil-48304340>. Acesso em: 13 jun. 2020.

MARX, Karl. O Capital: crítica da economia política. Livro 1: o processo de produção do capital. Tradução Rubens Enderle. 2. ed. São Paulo: Boitempo, 2017.

MISHEL, Lawrence. Uber and the labor market. Economic Policy Institute, Washington, D.C., 15 maio 2018. Disponível em: <www.epi.org/publication/uber-and-the-labor-market-uber-drivers-compensation-wages-and-the-scale-of-uber-and-the-gig-economy >. Acesso em: 26 abr. 2020.

MORAES, Rodrigo Bombonati de Souza; OLIVEIRA, Marco Antonio Gonsales de; ACCORSI, André. Uberização do trabalho: a percepção dos motoristas de transporte particular por aplicativo. Revista Brasileira de Estudos Organizacionais, Curitiba, v. 6, n. 3, p. 647681, 2019. Disponível em <https://rbeo.emnuvens.com.br/rbeo/article/view/216/pdf>. Acessado em: 17 jun. 2020.

MPT. Empresas de transporte, plataformas digitais e relações de emprego: um estudo do trabalho subordinado sob aplicativos. Brasília: Gráfica Movimento, 2018.

OLÍAS, Laura. El Tribunal Superior de Madrid da la razón a la Inspección: los 532 repartidores de Deliveroo son falsos autónomos. Eldiario.es, Madri, 23 jan. 2020.Disponível em: <www.eldiario.es/economia/Tribunal-Superior-Madrid-Deliveroo-Inspeccion_0_987951883.html>. Acesso em: 22 fev. 2020. 
PAULANI, Leda Maria. A crise do regime de acumulação com dominância da valorização financeira e a situação do Brasil. Estudos avançados, São Paulo, v. 23, n. 66, p. 25-39, 2009.

PICHONELLI, Matheus. Na linha de frente: como Uber, Rappi, Ifood, Loggi e afins reagiram à covid. Tilt, São Paulo, 23 mar. 2020. Disponível em: <www.uol.com.br/tilt/noticias/ redacao/2020/03/23/coronavirus-muda-rotina-nas-empresas-de-entrega-e-transporte-por-app.htm >. Acesso em: 25 mar. 2020.

PRESIDENTE da Rappi: Demanda por serviços em aplicativo de entregas triplica na pandemia. Portal Jovem Pan Online, São Paulo, 16 abr. 2020. Disponível em: <https:// jovempan.com.br/programas/jornal-da-manha/demanda-servicos-entregas-triplica.html>. Acesso em: 13 jun. 2020.

\section{RAPPI. Termos e condições de uso da plataforma virtual "Entregador Rappi". São Paulo, 2019. Disponível em: <https://legal.rappi.com/brazil/termos-e-condicoes-de-uso- -de-plataforma-virtual-entregador-rappi>. Acesso em: 21 jun. 2019.}

RAPPI BRASIL. Pois fiquem sabendo que a Rappi te ajuda, tá ok?. São Paulo, 10 fev. 2020. Twitter: @RappiBrasil. Disponível em: <https://twitter.com/RappiBrasil/status/1226920033907101697>. Acesso em: 17 jun. 2020.

REIS, Alessandro. Coronavírus: aplicativos buscam mais motoboys e vale até entrega com carro. UOL, São Paulo, 24 mar. 2020. Disponível em: <www.uol.com.br/carros/noticias/ redacao/2020/03/24/coronavirus-aplicativos-buscam-mais-motoboys-e-vale-ate-entrega-com-carro.htm>. Acesso em: 13 jun. 2020.

REMIR. Trabalhadores em plataformas digitais e a pandemia da covid-19: o necessário reconhecimento do vínculo de emprego. GGN, São Paulo, 23 abr. 2020. Disponível em: $<$ https://jornalggn.com.br/a-grande-crise/trabalhadores-em-plataformas-digitais-e-a-pandemia-da-covid-19-o-necessario-reconhecimento-do-vinculo-de-emprego>. Acesso em: 23 abr. 2020.

RIBEIRO, Gabriel Francisco. SP exige uso de máscara em apps como Uber, mas ninguém sabe como funcionará. Tilt, São Paulo, 30 abr. 2020. Disponível em: <www.uol.com.br/ tilt/noticias/redacao/2020/04/30/sp-exige-uso-de-mascara-em-apps-como-uber-mas-ninguem-sabe-como-funcionara.htm?cmpid=copiaecola>. Acesso em: 2 maio 2020.

ROCHA, Camilo. As decisões judiciais sobre Uber e motoristas, dentro e fora do Brasil. Nexo, São Paulo, 6 fev. 2020. Disponível em: <https://www.nexojornal.com.br/expresso/2020/02/06/As-decisões-judiciais-sobre-Uber-e-motoristas-dentro-e-fora-do-Brasil>. Acesso em: 22 fev. 2020. 
SALOMÃO, Karin. Ifood e Rappi: mais entregadores (e mais cobrança por apoio) na pandemia. Exame, São Paulo, 20 abr. 2020. Disponível em:<https://exame.abril.com.br/negocios/ coronavirus-leva-mais-entregadores-e-gorjetas-aos-apps-de-delivery>. Acesso em: 2 maio 2020.

SILVA, Victor Hugo. Ifood responde a ação do MPT-SP por omitir vínculo com motoboys. Tecnoblog, Americana, 28 jun.2019. Disponível em: <https://tecnoblog.net/296683/ifood-acao-mpt-sp-omitir-vinculo-motoboys >. Acesso em: 13 jun. 2020.

SRNICEK, Nick. Platform capitalism. Cambridge: Polity, 2017.

STANFORD, Jim. Subsidising billionaires: simulating the net incomes of UberX drivers in Australia. Camberra: Centre for Future Work, 2018.

THOMASON, Sarah; JACOBS, Ken; JAN, Sharon. Estimating the coverage of California's new AB 5 Law. UC Berkeley Center for Labor Research and Education. Berkeley, 12 nov.2019.Disponível em: <http://laborcenter.berkeley.edu/estimating-the-coverage-of-californias-new-ab-5-law>. Acesso em: 22 fev. 2020.

UBER. Brasil - termos de uso. São Paulo, 22 jan. 2020. Disponível em: <www.uber.com/ legal/pt-br/document/?name=general-terms-of-use\&country=brazil\&lang=pt-br $>$. Acesso em: 17 jun. 2020.

UBER BLOG. Novidades sobre a assistência financeira em razão da covid-19. São Paulo, 16 abr. 2020. Disponível em: <https://www.uber.com/pt-BR/blog/auxilio-financeiro/?utm_campaign=CM2043665-programmatic-display-brightroll_25_-99_BR-National_rider_all_bra_cpm_pt-BR_MWMSafety-L1ROCOVID-PO395563\&utm_medium=display-programmatic\&utm_source=brightroll>. Acesso em: 17 jun. 2020.

USTEK-SPILDA, Funda et al. The politics of covid-19: gig work in the coronavirus crisis. Red Pepper, Londres, 26 mar. 2020a. Disponível em: <www.redpepper.org.uk/gig-work-in-the-coronavirus-crisis>. Acesso em: 21 abr. 2020.

USTEK-SPILDA, Funda et al. The untenable luxury of self-isolation. New Internationalist, Oxford, 18 mar. 2020b.Disponível em: <https://newint.org/features/2020/03/18/untenable-luxury-self-isolation>. Acesso em: 3 maio 2020.

VALENDUC, Gérard. New forms of work and employment in the digital economy. In: SERRANO-PASCUAL, Amparo; JEPSEN, Maria (Ed.). The deconstruction of employment as a political question.1. ed. Londres: Palgrave Macmillan, 2019. p. 63-80. Disponível em:<https://doi.org/10.1007/978-3-319-93617-8_3> Acesso em: 12 jun. 2020. 